\title{
Grass Mix Pollen Antigen IgG Antibody Measurement
}

National Cancer Institute

\section{Source}

National Cancer Institute. Grass Mix Pollen Antigen Ig G Antibody Measurement. NCI

Thesaurus. Code C130104.

A measurement of the grass mix pollen antigen IgG antibody in a biological specimen. 